\title{
Ferritin is associated with the severity of lung involvement but not with worse prognosis in patients with COVID-19: data from two Italian COVID-19 Units.
}

\section{Francesco Carubbi ( $\square$ francescocarubbi@libero.it )}

University of L'Aquila

\section{Lia Salvati}

Ospedale SS Filippo e Nicola

\author{
Alessia Alunno \\ University of Perugia \\ Fabio Maggi \\ Ospedale SS Filippo e Nicola \\ Erika Borghi \\ University of L'Aquila \\ Rinalda Mariani \\ Ospedale SS Filippo e Nicola \\ Francesca Mai \\ University of L'Aquila \\ Maurizio Paoloni \\ Ospedale SS Filippo e Nicola \\ Claudio Ferri \\ University of L'Aquila \\ Giovambattista Desideri \\ University of L'Aquila

\section{Sabrina Cicogna \\ University of L'Aquila \\ Davide Grassi \\ University of L'Aquila}

\section{Research Article}

Keywords: SARS-CoV-2, COVID-19, ferritin, SARS-CoV-2 pulmonary involvement, computed tomography

Posted Date: November 9th, 2020

DOl: https://doi.org/10.21203/rs.3.rs-103672/v1

License: @ (i) This work is licensed under a Creative Commons Attribution 4.0 International License. Read Full License

Version of Record: A version of this preprint was published at Scientific Reports on March 1st, 2021. See the published version at https://doi.org/10.1038/s41598-021-83831-8. 


\section{Abstract}

The coronavirus 2019 disease (COVID-19) is characterised by a heterogeneous clinical presentation, a complex pathophysiology and a wide range of imaging findings, depending on disease severity and time course. We conducted a retrospective evaluation of hospitalized patients with proven SARS-CoV-2 infection, clinical signs of COVID-19 and computed tomography (CT) scan-proven pulmonary involvement, in order to identify relationships between clinical, serological, imaging data and disease outcomes in patients with COVID-19. Clinical and serological records of patients admitted to two COVID-19 Units of the Abruzzo region in Italy with proven SARS-CoV-2 pulmonary involvement investigated with CT scan, assessed at the time of admission to the hospital, were retrospectively evaluated.

Sixty-one patients (22 females and 39 males) of median age 65 years were enrolled. Fifty-six patients were discharged while death occurred in 5 patients. None of the lung abnormalities detected by CT was different between discharged and deceased patients. No differences were observed in the features and extent of pulmonary involvement according to age and gender. Logistic regression analysis with age and gender as covariates demonstrated that ferritin levels over the $25^{\text {th }}$ percentile were associated with the involvement of all 5 pulmonary lobes $(\mathrm{OR}=14.5,95 \% \mathrm{Cl}=2.3-90.9, \mathrm{p}=0.004)$, the presence of septal thickening $(\mathrm{OR}=8.2,95 \% \mathrm{Cl}=1.6-40.9, \mathrm{p}=0.011)$ and the presence of mediastinal lymph node enlargement $(\mathrm{OR}=12.0,95 \%$ $\mathrm{Cl}=1.1-127.5, \mathrm{p}=0.039)$ independently of age and gender.

We demonstrated that ferritin levels over the $25^{\text {th }}$ percentile are associated with a more severe pulmonary involvement, independently of age and gender and not associated with disease outcomes. The identification of reliable biomarkers in patients with COVID-19 may help guiding clinical decision, tailoring therapeutic approaches and ultimately improving the care and prognosis of patients with this disease.

\section{Introduction}

In late 2019, an outbreak of viral pneumonia caused by a novel coronavirus, the severe acute respiratory syndrome coronavirus 2 (SARS-CoV-2) was identified in Wuhan, China (1); subsequently, the coronavirus 2019 disease (COVID-19) spread worldwide, and on March 11, 2020, the WHO declared COVID-19 a global pandemic (2).

COVID-19 clinical presentation ranges from asymptomatic infection to interstitial pneumonia, respiratory failure, acute respiratory distress syndrome (ARDS) and sepsis (3). The pathophysiology is complex, involving immune and hematologic systems, epithelial cells and vascular system (4). Several pro-inflammatory cytokines and chemokines, interleukin (IL)-1 $\beta$, IL-2, IL-6, IL-7, IL-10, tumour necrosis factor-a (TNFa), granulocyte colony-stimulating factor (G-CSF), interferon (IFN) $y$-induced protein 10 (IP-10/CXCL10), monocyte chemoattractant protein 1 (MCP-1), macrophage inflammatory protein 1a (MIP$1 \mathrm{a} / \mathrm{CCL} 3)$, have been detected in the bloodstream and target tissue of COVID-19 patients $(1,3,5)$. Severe lymphopenia is a very early sign of the disease, preceding pulmonary problems, and tends to normalize as the patient improves. In particular, $\mathrm{T}$ lymphocytes including CD4 and CD8 subtypes and NK cells are reduced in patients with severe disease (6). Conversely, monocytes and macrophages are increased, explaining elevated levels of some pro-inflammatory cytokines. All this fits with the evidence that the predominant pattern of lung lesions in patients with COVID-19 patients is a diffuse alveolar damage, with the presence of platelet-fibrin thrombi in small arterial vessels, and the great majority of the inflammatory cells infiltrating the lungs are monocytes, macrophages and $\mathrm{CD} 4^{+}$lymphocytes $(7,8)$.

Further events lead to activation of the coagulation cascade through endothelial and tissue factor pathways, paralleling the systemic inflammation $(9,10)$. Moreover, some Authors suggested that COVID-19 might be considered as a peculiar cardiovascular (CV) disease based on predisposing patients to arterial and venous thrombosis and particularly as consequence of endothelial dysfunction $(11,12)$. Indeed, it has been reported that CV complications are quickly emerging as a key threat in COVID-19 beyond respiratory involvement. The mechanisms underlying the disproportionate effect of SARS-CoV-2 infection on patients with CV comorbidities are not yet fully elucidated. Nevertheless, laccarino et al recently showed that in patients with COVID-19 mortality is predicted by age and comorbidities, particularly diabetes mellitus, chronic obstructive pulmonary disease, and chronic kidney disease but not hypertension (13).

Page $2 / 20$ 
The massive release of pro-inflammatory mediators and the aberrant activation of the immune and coagulation systems, resembles the so-called cytokine release syndrome, a group of conditions sharing the same pathogenic mechanism, although with a different aetiology (14). This cytokine storm accounts for the two main causes of mortality in COVID-19, ARDS and secondary haemophagocytic lymphohistiocytosis, the latter occurring in a small subset of patients (15). Furthermore, since increased levels of ferritin along with a cytokine storm have been described in patients with severe COVID-19 (16), it has been speculated that COVID-19 may be included in the spectrum of the hyperferritinemic syndromes (15).

COVID-19 pneumonia displays a wide range of imaging findings, depending on disease severity and time course, and can overlap with a variety of infectious and non-infectious pulmonary diseases. The choice of imaging in COVID-19 is left to the judgement of clinical teams at the point-of-care accounting for the differing attributes of X-ray and computed tomography (CT), local resources, and expertise (17). However, CT is more sensitive for early parenchymal lung disease, disease progression, and alternative diagnoses including acute heart failure from COVID-19 myocardial injury and pulmonary thromboembolism (18). Typically, COVID-19 pneumonia is characterised by bilateral peripheral patchy ground-glass opacities (GGO) with or without consolidation; superimposed interlobular septal thickening can also be present, resulting in a crazy-paving pattern $(19,20)$. Pleural effusion or septal thickening have been rarely described (21), while recently an Italian study described lymphadenopathy in up to $58 \%$ of cases (22). GGO alone, followed by GGO with consolidation, is the most frequent finding in mild cases, while in severe cases with ARDS widespread dense consolidative opacification are present (18).

The aim of this study was to describe clinical, serological and CT imaging features of a cohort of patients with COVID-19 pneumonia and identify possible relationships between the variables and disease outcomes (admission to intensive care unit (ICU) and/or death).

\section{Methods}

\section{Patient cohort and data collection}

Clinical and serological records of patients admitted to two COVID-19 Units of the Abruzzo region in Italy (S. Salvatore Hospital, L'Aquila and SS Filippo e Nicola Hospital, Avezzano) with proven SARS-CoV-2 pulmonary involvement investigated with CT scan, assessed at the time of admission to the hospital, were retrospectively evaluated. All patients presented the clinical and laboratory signs of COVID-19 infection, as assessed by positive SARS-CoV-2 RT-PCR testing.

Collected data included: age, gender, days of symptoms before the CT scan, red blood cell count, hemoglobin (Hb), platelet (PLT) count, white blood cell (WBC) count, absolute neutrophil count (ANC), absolute lymphocyte count (ALC), absolute monocyte count (AMC), lymphocyte subpopulation (CD3, CD4, CD8, CD16, CD19), erythrocyte sedimentation rate (ESR), Creactive protein (CRP), ferritin, D-dimer, fibrinogen, lactate dehydrogenase (LDH), procalcitonin, arterial oxygen partial pressure:fractional inspired oxygen ratio (PaO2/FiO2). Neutrophils:lymphocytes $(\mathrm{N}: \mathrm{L})$ ratio and ferritin:ESR ratio were calculated based on the available data. Anemia was defined according to the WHO criteria as Hb values below $12 \mathrm{~g} / \mathrm{dl}$ in females and $13 \mathrm{~g} / \mathrm{dl}$ in males (23). All the other cytopenias were defined according to the reference levels of the local laboratory (leukopenia: $\mathrm{WBC}<4.00 \times 10^{3} / \mathrm{uL}$; neutropenia: ANC $<2.00 \times 10^{3} / \mathrm{uL}$; lymphocytopenia: ALC $<0.80 \times 10^{3} / \mathrm{uL}$ ).

All patients underwent chest CT and the images were examined by an independent radiologist (FB) with more than 10-year experience on chest CT imaging. The information collected were: lobes involved and presence/absence of: GGOs, parenchymal consolidation, septal thickening, pleural effusion, mediastinal lymph node enlargement (24). Two semi-quantitative scoring systems were used to quantify the extension of the disease: i. each of the 5 lobes (right upper lobe, right middle lobe, right lower lobe, left upper lobe and left lower lobe) was scored on a scale of 0-3 ( 0 : no lesion, 1: $<1 / 3$ of the lobe volume involved, 2: $>1 / 3$ and $<2 / 3$ of the lobe volume involved, 3: $>2 / 3$ of the lobe volume involved) (score A) (25); ii. each of the five lung lobes was assessed for degree of involvement and classified as none ( $0 \%)$, minimal (1\%-25\%), mild (26\%-50\%), moderate $(51 \%-$ $75 \%)$, or severe $(76 \%-100 \%)$. No involvement corresponded to a lobe score of 0 , minimal involvement to a lobe score of 1 , mild involvement to a lobe score of 2 , moderate involvement to a lobe score of 3 , and severe involvement to a lobe score of 4 (Score 
B) (26). An overall lung "total severity score" was reached by summing the five lobe scores (Score A, range of possible scores, $0-15$; Score B range of possible scores, $0-20$ ).

\section{Statistical analysis}

Data were analyzed with STATA/SE 16.1. The Mann Whitney U test was used to compare continuous variables while the $\chi^{2}$ and Fisher's exact tests were used as needed for categorical variables. Bivariate correlation (Spearman's $\rho$ ) and binary logistic regression analysis were also performed. All tests were two tailed and values of $p<0.05$ were considered statistically significant.

\section{Results}

\section{Characteristics of the study cohort}

Sixty-one patients (22 females and 39 males) with a median age of 65 years (range 32-93 years) were enrolled (Table 1). Acute phase reactants were abnormal in the majority of patients while with regard to blood cell counts, 26/60 patients (43\%) did not display any cytopenia. Anemia was detectable in 22/60 patients (37\%), leukopenia in 9 patients (15\%) and thrombocytopenia in $11 / 60$ patients (18\%). In $27 / 60$ patients (45\%) only one cytopenia was present, in $6 / 60$ patients (10\%) cytopenia involved 2 cell lines, in only 1 patient involved all the 3 cell lines. A reduction of ANC was observed in $6 / 60$ patients (10\%) while ALC was below the lower limit in $15 / 60$ patients (25\%). Of interest, $7 / 60$ patients $(12 \%)$ displayed lymphocytosis. The mean N:L ratio was 5.07. The ferritin value was available in 51 out of 61 patients and increased in 38 of them (74\%). The average time between the onset of respiratory symptoms and the chest CT was 5.69 days. Overall, pulmonary involvement was moderate to severe, with $59 \%$ of subjects having 5 lobes involved and 58 patients (95\%) displaying bilateral disease. About half of the patients displayed only GGO and the other half both GGO and consolidation. Pleural effusion was observed only in a small number of patients $(\mathrm{N}=11 ; 18 \%)$ while 46 patients $(75 \%)$ displayed septal thickening. Mediastinal lymph node enlargement was detected in $20(33 \%)$ of patients. Mean PaO2/FiO2 value was 300.1, with only 5/58 (9\%) patients displaying normal values (> 400), 23/58 (40\%) patients displaying slight impairment (300-400); 24/58 (41\%) patients displaying moderate impairment (200-300) and 6/58 (10\%) patients displaying severe impairment. The average values of the two CT severity scores were 5.85 and 6.69 respectively. Table 2 shows the correlations between pulmonary involvement and different serological variables. As far as the disease outcomes are concerned, 56 patients (92\%) were discharged while 5 patients (8\%) deceased. Of the 56 discharged patients, five $(9 \%)$ required admission to ICU before discharge.

\section{Subgroup analysis by age and gender}

When patients were divided according to the age (below or over 65 years, Table 3) a few variables resulted significantly different. In particular, lower CD8 lymphocyte counts and lower Hb levels along with higher CRP and D-dimer levels were observed in patients over 65 years (all $\mathrm{p}$ values $<0.05$ ). As expected by lower $\mathrm{Hb}$ values, anemia was more prevalent in patients over the age of $65(p=0.032)$. Of interest, while the prevalence of thrombocytopenia, leukopenia and lymphopenia was similar in the 2 groups, all patients with neutropenia were below the age of $65(p=0.009)$ and all but one patient with lymphocytosis were over the age of $65(p=0.05)$. In addition, the N:L ratio was significantly higher in patients over 65 years of age $(p=0.03)$. To note, neither the features and extent of pulmonary involvement, nor the functional impairment seemed to be influenced by age of onset. Likewise, no difference in the features and extent of pulmonary involvement, nor in the functional impairment emerged comparing males to females. However, males displayed significantly higher levels of ferritin and, as a consequence, of the ferritin:ESR ratio.

\section{Subgroup analysis by ferritin levels}

No difference in the extent or severity of pulmonary manifestations was observed. We divided the 51 patients with available ferritin values according to percentiles (Table 4) rather than using the reference level of the local laboratory to ensure generalizability of the results. Patients with ferritin values over the $25^{\text {th }}$ percentile were more frequently males and also displayed higher levels of fibrinogen, LDH and procalcitonin compared to those with ferritin levels below the $25^{\text {th }}$ percentile. To 
note, the extent of pulmonary involvement (number of lobes affected, bilateral involvement, and severity scores) as well as the prevalence of septal thickening and mediastinal lymph node enlargement were significantly higher in patients with higher levels of ferritin while the functional impairment (PAO2/FiO2) was more pronounced in this group.

We subsequently performed logistic regression analysis and since older age and male gender have been identified as predictors of more severe disease in previous studies and ferritin was significantly higher in males in our cohort, we included both age and gender as covariates. Ferritin levels over the $25^{\text {th }}$ percentile were associated with the involvement of all 5 pulmonary lobes (Odds ratio $(O R)=14.5,95 \% \mathrm{Cl}=2.3-90.9, \mathrm{p}=0.004)$, the presence of septal thickening $(\mathrm{OR}=8.2,95 \% \mathrm{Cl}=1.6-40.9$, $\mathrm{p}=0.011)$ and the presence of mediastinal lymph node enlargement $(\mathrm{OR}=12.0,95 \% \mathrm{Cl}=1.1-127.5, \mathrm{p}=0.039)$ independently of age and gender. The N:L ratio was also associated with the presence of septal thickening $(O R=2.0,95 \% \mathrm{Cl}=1.2-3.5, p=0.008)$ but at multivariate analysis only ferritin remained significantly associated with this pulmonary manifestation $(\mathrm{OR}=5.1,95 \% \mathrm{Cl}=$ $1.1-24.3, p=0.043)$.

\section{Subgroup analysis by disease outcomes}

When comparing discharged patients according to their need to be admitted to ICU before discharge, we observed significantly higher severity scores and significantly lower PAO2/FiO2 values in patients needing ICU, as well as higher D-dimer and LDH values (Table 5). However, none of the other variables was significantly different between the groups. When comparing discharged and deceased patients it emerged that deceased patients were older, with higher WBC and ANC counts and higher $\mathrm{N}: \mathrm{L}$ ratios along with higher $\mathrm{LDH}$ and procalcitonin levels and lower $\mathrm{PaO} 2 / \mathrm{FiO} 2$ values. None of the lung abnormalities detected by CT was different between discharged and deceased patients.

\section{Discussion}

Although in the majority of patients COVID-19 is characterized by mild to moderate symptoms, it is burdened by consistent morbidity and mortality due to respiratory failure, ARDS and sepsis (3).

In our cohort the prognosis was rather good despite the severity of pulmonary involvement, with only a small number of subjects needing to be transferred to ICU and/or eventually deceased. In addition, we demonstrated and quantified for the first time a strong association between ferritin levels and the severity of pulmonary involvement independently of age and gender.

Since December 2019 an increasing number of articles describing the clinical, serological and histological features of patients with COVID-19 across the world have been published (27). Italy has been early and dramatically affected by COVID-19 although with a large diversity across the Country (28). The Abruzzo region is within the 10 less affected regions per number of cases but with a relatively high case fatality ratio of $13 \%$. However, despite the severity of the pulmonary involvement, the overall prognosis in our cohort was good with most of the patients requiring ICU being subsequently discharged and only $8 \%$ patients deceased. Furthermore, our data regarding the prevalence of different pulmonary lesions in COVID-19 partially fit with the previous literature $(29,30)$.

It has been speculated that pulmonary oedema and hyaline membrane formation may be the underlying pathological driver of GGO sign $(31,32)$. GGO may develop into reticular interlobular septa thickening and crazy paving pattern, indicating that the infection leads to diffuse alveolar oedema and interstitial inflammation (33). Of interest, septal thickening was the most frequent lesion in our cohort observed in $75 \%$ of patient. Multifocal, patchy, or segmental consolidation, distributed in subpleural areas or along bronchovascular bundles, is usually detected in the 2-64\% of COVID-19 pneumonia $(21,30)$ andhttps://doi.org/10.1097/RLI. 0000000000000672 may relate to cellular fibromyxoid exudates in alveoli $(31,32)$. Several data suggest that the presence of consolidation and its increase overtime could be an indicator of disease progression (33-35), however this was not the case in our cohort. We confirmed that pleural effusion is a rare imaging finding and none of our patients displayed coexisting lymphadenopathy. Based on the experience of other viral pneumonia such as influenza and other coronavirus diseases, the presence of pleural effusion may suggest a poor prognosis in COVID-19 patients $(30,31,35-40)$ and if coexisting with lymphadenopathy bacterial superinfection or another diagnosis should be ruled out $(29,31)$. Among 
demographic and serological features, several parameters, such as older age and male gender, have been associated with more severe COVID-19 prognosis (13). Furthermore, higher ferritin levels have been described in patients with more severe disease $(16,41)$. This finding fits with the concept of hyperinflammation in COVID-19 and it has been speculated that COVID-19 with pulmonary involvement may be included within the spectrum of hyperferritinemic syndrome $(15,42)$. Of interest, a recent study observed that hyperferritinemia was related to higher mortality in patients over 70 years of age. In particular, hyperferritinemia favored a better stratification of mortality risk in this population (43).

In our cohort, age was not related to ferritin levels but male patients displayed significantly higher levels. Of interest, however, when stratifying patients according to the levels of ferritin, the association between higher ferritin levels and a more sever clinical picture independently of age and gender became evident. Hyperferritinemic syndromes share clinical and serological features such as fever, cytopenias, multiorgan involvement and coagulopathy (44), most of which can also be observed in COVID-19. In fact, despite a lung-centric immunopathology, currently available data suggest that the clinical spectrum of COVID-19 is not limited to lung involvement, but rather represents a multisystem illness (4). Patients with higher ferritin levels displayed a higher N:L ratio, which has been associated with more severe pulmonary involvement in COVID-19 $(45,46)$. In addition, higher D-dimer levels, hinting coagulation abnormalities, were also detected in COVID-19 patients with higher ferritin levels. The most intriguing finding is that ferritin was not associated with the disease outcome (discharge, admission to ICU or death) and neither was D-dimer, the latter in contrast with a retrospective Chinese study (3). It is therefore tempting to speculate that ferritin may have a pathogenic role in the development of lung damage in COVID-19 but the exact mechanisms need to be fully elucidated. Inflammation is an essential part of an effective immune response and it has also clearly been indicated as a specific promoter of endothelial dysfunction and enhancer of the atherosclerotic process with increasing the CV risk (47). Since SARS-CoV-2 can induce excessive and prolonged cytokine/chemokine responses that may eventually lead to death, the identification of reliable biomarkers enabling early stratification of patients developing cytokine storm and at which extent is warranted. This would also allow tailoring of immunomodulatory treatment strategies. This bulk of evidence may also support the "endothelial" hypothesis with the thrombotic or thromboembolic implications COVID-19-dependent associated to the cytokine storm (48).

We acknowledge that our study displays some limitations, such as its retrospective nature, the small number of patients and the lack of data on comorbidities and pro-inflammatory cytokine levels.

\section{Conclusions}

We demonstrated for the first time that ferritin levels over the $25^{\text {th }}$ percentile are associated with severe pulmonary involvement as detected by CT scan but not with the disease outcome. We also confirmed that CT findings of GGO with or without consolidation are the earliest and common visible manifestation of COVID-19 pneumonia, highlighting its central role in the diagnosis and severity evaluation of the disease. An accurate assessment of radiologic and pathologic features in COVID-19 patients is warranted to gain further knowledge on disease pathogenesis, clinical course and prognosis. This, along with the implementation of reliable biomarkers of lung disease severity in COVID-19 patients will allow early diagnosis, tailored treatment and ultimately improve patient care.

\section{References}

1. Huang C, Wang Y, Li X et al. Clinical features of patients infected with 2019 novel coronavirus in Wuhan, China. Lancet.395(10223):497-506 (2020)

2. WHO Director-General's opening remarks at the media briefing on COVID-19 - 11 March 2020. https://www.who.int/dg/speeches/detail/who-director-general-s-opening-remarks-at-the-media-briefing-on-covid-19, 11march-2020

3. Zhou F, Yu T, Du, R et al. Lancet Clinical course and risk factors for mortality of adult inpatients with COVID-19 in Wuhan, China: a retrospective cohort study. Lancet.395(10229):1054-1062 (2020) 
4. Robba C, Battaglini D, Pelosi P, et al. Multiple organ dysfunction in SARS-CoV-2: MODS-CoV-2. [published online June 22, 2020]. Expert Rev Respir Med.14(9):865-868 (2020)

5. Conti P, Ronconi G, Caraffa A et al. Induction of pro-inflammatory cytokines (IL-1 and IL-6) and lung inflammation by Coronavirus-19 (COVI-19 or SARS-CoV-2): anti-inflammatory strategies. J Biol Regul Homeost Agents.34(2):327-331 (2020)

6. Zhang W, Zhao Y, Zhang F et al. The use of anti-inflammatory drugs in the treatment of people with severe coronavirus disease 2019 (COVID19): the experience of clinical immunologists from China. Clin Immunol.214:108393 (2020)

7. Carsana L, Sonzogni A, Nasr A et al. Pulmonary post-mortem findings in a series of COVID-19 cases from northern Italy: a two-centre descriptive study. Lancet Infect Dis.S1473-3099(20)30434-5 (2020)

8. Ackermann M, Verleden SE, Kuehnel M et al. Pulmonary vascular endothelialitis, thrombosis, and angiogenesis in Covid19. N Engl J Med.383(2):120-128 (2020)

9. Tang N, Li D, Wang X, et al. Abnormal coagulation parameters are associated with poor prognosis in patients with novel coronavirus pneumonia. J Thromb Haemost.18(4):844-847 (2020)

10. Levi M, Thachil J, Iba T, et al. Coagulation abnormalities and thrombosis in patients with COVID-19. Lancet Haematol.7(6):e438-e440 (2020)

11. Bikdeli B, Madhavan MV, Jimenez D et al. COVID-19 and thrombotic or thromboembolic disease: implications for prevention, antithrombotic therapy, and follow-up: JACC state-of-the-art review. J Am Coll Cardiol.75(23):2950-297 (2020)

12. Sardu C, Gambardella J, Morelli MB, et al. Hypertension, thrombosis, kidney failure, and diabetes: is COVID-19 an endothelial disease? A comprehensive evaluation of clinical and basic evidence. J Clin Med.9(5):1417 (2020)

13. laccarino G, Grassi G, Borghi $C$ et al, SARS-RAS Investigators. Age and multimorbidity predict death among COVID-19 patients: results of the SARS-RAS study of the Italian society of hypertension Hypertension.76(2):366-372 (2020)

14. Mehta P, McAuley DF, Brown M, et al. HLH Across Speciality Collaboration, UK. COVID-19: consider cytokine storm syndromes and immunosuppression 395(10229):1033-1034 (2020)

15. Alunno A, Carubbi F, Rodriguez-Carrio J. Storm, typhoon, cyclone or hurricane in patients with COVID-19? Beware of the same storm that has a different origin. RMD Open.6(1):e001295 (2020)

16. Ruan Q, Yang K, Wang W, et al. Clinical predictors of mortality due to COVID-19 based on an analysis of data of 150 patients from Wuhan, China. Intensive Care Med.46(5):846-848 (2020)

17. Rubin GD, Ryerson CJ, Haramati LB et al. The role of chest imaging in patient management during the COVID-19 pandemic: A multinational consensus statement from the Fleischner Society. 296(1):172-180 (2020)

18. El Homsi M, Chung M, Bernheim A et al. Review of chest CT manifestations of COVID-19 infection. Eur J Radiol Open.7;7:100239 (2020)

19. Ai T, Yang Z, Hou H et al. Correlation of chest CT and RT-PCR testing for coronavirus disease 2019 (COVID-19) in China: A report of 1014 cases. Radiology.296(2):E32-E40 (2020)

20. Hani C, Trieu NH, Saab I et al. COVID-19 pneumonia: A review of typical CT findings and differential diagnosis. Diagn Interv Imaging.101(5):263-268 (2020)

21. Bernheim A, Mei X, Huang M et al. Chest CT findings in coronavirus disease-19 (COVID-19): relationship to duration of infection. Radiology.295(3):200463 (2020)

22. Caruso D, Zerunian M, Polici M et al. Chest CT features of COVID-19 in Rome, Italy. Radiology.296(2):E79-E85 (2020)

23. Valent P. Low blood counts: immune mediated, idiopathic, or myelodysplasia hematology. Am Soc Hematol Educ Program.2012:485-491 (2012)

24. Hansell DM, Bankier AA, MacMahon H, et al. Fleischner Society: glossary of terms for thoracic imaging. Radiology.246:697-722 (2008)

25. Shen C, Yu N, Cai S et al. Quantitative computed tomography analysis for stratifying the severity of Coronavirus Disease 2019. J Pharm Anal.10(2):123-129 (2020)

26. Chung M, Bernheim A, Mei X et al. CT imaging features of 2019 novel coronavirus (2019-nCoV). Radiology.295(1):202-207 (2020)

Page $7 / 20$ 
27. The Johns Hopkins Coronavirus resource center, mortality analysis. https://coronavirus.jhu.edu/data/mortality

28. The Italian Ministry of Health. http://www.salute.gov.it/

29. Bao C, Liu X, Zhang H, et al. Coronavirus disease 2019 (COVID-19) CT findings: a systematic review and meta-analysis. J Am Coll Radiol.17(6):701-709 (2020)

30. Li K, Wu J, Wu F et al. The clinical and chest CT features associated with severe and critical COVID-19 pneumonia. Invest Radiol.55(6):327-331 (2020)

31. Ye Z, Zhang Y, Wang Y, et al. Chest CT manifestations of new coronavirus disease 2019 (COVID-19): a pictorial review. Eur Radiol.30(8):4381-4389 (2020)

32. Xu Z, Shi L, Wang Y et al. Pathological findings of COVID-19 associated with acute respiratory distress syndrome. Lancet Respir Med.8(4):420-422 (2020)

33. Song F, Shi N, Shan F et al. Emerging 2019 novel coronavirus (2019-nCoV) pneumonia. Radiology.295(1):210-217 (2020)

34. Pan F, Ye T, Sun $P$ et al. Time course of lung changes at chest CT during recovery from coronavirus disease 2019 (COVID19). 295(3):715-721 (2020)

35. Shi H, Han X, Jiang $\mathrm{N}$ et al. Radiological findings from 81 patients with COVID-19 pneumonia in Wuhan, China: a descriptive study. Lancet Infect Dis.20(4):425-434 (2020)

36. Das KM, Lee EY, Al Jawder SE, et al. Acute Middle East respiratory syndrome coronavirus: temporal lung changes observed on the chest radiographs of 55 patients. AJR Am J Roentgenol.205:W267-74 (2015)

37. de Wit E, van Doremalen N, Falzarano D, et al. SARS and MERS: recent insights into emerging coronaviruses. Nat Rev Microbiol.14:523-534 (2016)

38. Hui DSC, Zumla A. Severe acute respiratory syndrome: historical, epidemiologic, and clinical features. Infect Dis Clin North Am.33:869-889 (2019)

39. Zu ZY, Jiang MD, Xu PP, et al. Coronavirus disease 2019 (COVID-19): a perspective from China. Radiology.296(2):E15-E25 (2020)

40. Kooraki S, Hosseiny M, Myers L, et al. Coronavirus (COVID-19) outbreak: what the department of radiology should know. J Am Coll Radiol.17:447-451 (2020)

41. Lin Z, Long F, Yang Y, et al. Serum ferritin as an independent risk factor for severity in COVID-19 patients. J Infect.S01634453(20)30434-30435 (2020)

42. McGonagle D, Sharif K, O'Regan A, et al. The role of cytokines including interleukin-6 in COVID-19 induced pneumonia and macrophage activation syndrome-like disease. Autoimmun Rev.19(6):102537 (2020)

43. Goldhaber G, Segal G, Dagan A. Hyperferritinemia in the elderly can differentiate the bad from the worst: A retrospective cohort analysis. Medicine (Baltimore).99(31):e21419 (2020)

44. Rosário C, Zandman-Goddard G, Meyron-Holtz EG, et al. The hyperferritinemic syndrome: macrophage activation syndrome, Still's disease, septic shock and catastrophic antiphospholipid syndrome. BMC Med.11:185 (2013)

45. Kong M, Zhang H, Cao X, et al. Higher level of neutrophil-to-lymphocyte is associated with severe COVID-19. Epidemiol Infect.148:e139 (2020)

46. Liu J, Liu Y, Xiang P et al. Netrophil-to-lymphocyte ratio predicts critical illness patients with 2019 coronavirus disease in the early stage. J Transl Med.18(1):206 (2020)

47. Grassi D, Desideri G, Ferri C. Cardiovascular risk and endothelial dysfunction: the preferential route for atherosclerosis. Curr Pharm Biotechnol.12(9):1343-1353 (2011)

48. Jung F, Krüger-Genge A, Franke RP, et al. COVID-19 and the endothelium. Clin Hemorheol Microcirc.75(1):7-11 (2020)

\section{Declarations}


When the COVID Unit was established in our hospital, an informed consent form was developed and all patients were requested to sign it upon admission. The form asked the person to provide consent to share their anonymized clinical, serological, and radiological data obtained during the stay with the international scientific community (in form of multidisciplinary meetings, congress presentations, or research articles in a scientific journal). Therefore, due to the retrospective and observational nature of our study, we did not submit it to an additional ethics committee since all patients already provided their consent.

\section{AUTHOR CONTRIBUTIONS}

F.C., L.S., A.A., D.G., conceived and developed the study, supervised the acquisition of the data, analyzed and interpreted the data. Fa.M. analyzed CT scan. E.B., R.M., Fr.M., M.P., assisted in collecting clinical information about the patients and helped to interpret the data. C.F., G.D., S.C. critically reviewed the manuscript.

All authors edited and approved the final version of this manuscript.

\section{FUNDING SOURCE}

This study did not receive specific funding.

\section{DECLARATION OF COMPETING INTEREST}

Authors have no conflicts of interest to disclose with regard to the present manuscript.

\section{Tables}




\begin{tabular}{|c|c|c|}
\hline & Mean & SD \\
\hline Age (years) & 66.02 & 14.95 \\
\hline Days of symptoms before CT & 5.69 & 3.16 \\
\hline WBC (Nx103/uL) & 6.26 & 2.72 \\
\hline ANC $\left(\mathrm{N} \times 10^{3} / \mathrm{uL}\right)$ & 4.61 & 2.61 \\
\hline ALC $\left(\mathrm{N} \times 10^{3} / \mathrm{uL}\right)$ & 1.18 & 0.49 \\
\hline AMC $\left(\mathrm{N} \times 10^{3} / \mathrm{uL}\right)$ & 0.44 & 0.25 \\
\hline $\mathbf{N}: L$ ratio & 5.07 & 4.59 \\
\hline $\mathrm{CD}^{+}$cells $\left(\mathrm{N} \times 10^{3} / \mathrm{uL}\right)$ & 902.73 & 430.87 \\
\hline $\mathrm{CD}^{+}$cells $\left(\mathrm{N} \times 10^{3} / \mathrm{uL}\right)$ & 525.22 & 226.03 \\
\hline CD8 ${ }^{+}$cells $\left(\mathrm{Nx} 10^{3} / \mathrm{uL}\right)$ & 363.22 & 238.60 \\
\hline $\mathrm{CD}_{19}{ }^{+}$cells $\left(\mathrm{Nx} 10^{3} / \mathrm{uL}\right)$ & 115.46 & 60.08 \\
\hline CD16 ${ }^{+}$cells $\left(\mathrm{Nx} 10^{3} / \mathrm{uL}\right)$ & 194.03 & 138.04 \\
\hline CD4/CD8 ratio & 2.00 & 1.55 \\
\hline $\mathrm{Hb}(\mathrm{g} / \mathrm{L})$ & 13.18 & 1.72 \\
\hline PLTs & 222.47 & 80.66 \\
\hline ESR (mm 1h) & 65.88 & 30.06 \\
\hline CRP (mg/dl) & 5.16 & 4.72 \\
\hline Ferritin & 813.54 & 929.23 \\
\hline Ferritin:ESR ratio & 21.00 & 37.42 \\
\hline D-dimer & 1.69 & 2.75 \\
\hline Fibrinogen & 556.44 & 151.62 \\
\hline LDH & 322.16 & 145.26 \\
\hline Procalcitonin & 0.22 & 0.36 \\
\hline $\mathrm{PaO2} / \mathrm{FiO} 2$ & 300.07 & 84.13 \\
\hline Severity ScoreA & 5.85 & 2.85 \\
\hline \multirow[t]{2}{*}{ Severity Score B } & 6.69 & 3.77 \\
\hline & $\mathbf{N}$ & $\%$ \\
\hline \multicolumn{3}{|l|}{ Gender } \\
\hline $\mathrm{F}$ & 22 & 36 \\
\hline M & 39 & 64 \\
\hline No. of lobes affected & & \\
\hline
\end{tabular}




\begin{tabular}{|c|c|c|}
\hline 1 & 2 & 3 \\
\hline 2 & 7 & 11 \\
\hline 3 & 7 & 11 \\
\hline 4 & 9 & 15 \\
\hline 5 & 36 & 59 \\
\hline Bilateral lung disease & 58 & 95 \\
\hline \multicolumn{3}{|l|}{ Type of parenchymal lesions } \\
\hline Neither ground glass opacities nor consolidation & 0 & 0 \\
\hline Ground glass opacities only & 32 & 52 \\
\hline Consolidation only & 0 & 0 \\
\hline Ground glass opacities and consolidation & 29 & 48 \\
\hline Septal thickening & 46 & 75 \\
\hline Pleural effusion & 11 & 18 \\
\hline Mediastinal lymph node enlargement & 20 & 33 \\
\hline \multicolumn{3}{|l|}{ Outcome } \\
\hline Discharged & 56 & 92 \\
\hline With ICU admission & 5 & 9 \\
\hline Without ICU admission & 51 & 91 \\
\hline Deceased & 5 & 8 \\
\hline
\end{tabular}

Table 2. Correlations between pulmonary involvement and serological variables. 


\begin{tabular}{|c|c|c|c|}
\hline \multirow[t]{9}{*}{$\mathrm{PaO} / \mathrm{FiO} 2$} & variable & Spearman's $\rho$ & $p$ value \\
\hline & ANC & -0.325 & 0.013 \\
\hline & $\mathrm{N}: L$ ratio & -0.375 & 0.004 \\
\hline & CRP & -0.303 & 0.022 \\
\hline & D-dimer & -0.268 & 0.048 \\
\hline & LDH & -0.504 & $<0.0001$ \\
\hline & Procalcitonin & -0.395 & 0.003 \\
\hline & Severity score A & -0.506 & $<0.0001$ \\
\hline & Severity score B & -0.518 & $<0.0001$ \\
\hline \multirow[t]{15}{*}{ CT Severity score A } & variable & Spearman's $\rho$ & $p$ value \\
\hline & ANC & 0.305 & 0.017 \\
\hline & ALC & -0.486 & $<0.0001$ \\
\hline & $\mathrm{N}: L$ ratio & 0.496 & $<0.0001$ \\
\hline & $\mathrm{CD}^{+}$cells & -0.559 & $<0.0001$ \\
\hline & $\mathrm{CD} 4^{+}$cells & -0.531 & 0.001 \\
\hline & $\mathrm{CD}^{+}$cells & -0.430 & 0.008 \\
\hline & CD16 ${ }^{+}$cells & -0.328 & 0.048 \\
\hline & ESR & 0.298 & 0.032 \\
\hline & CRP mg/dl & 0.532 & $<0.0001$ \\
\hline & Ferritin & 0.529 & $<0.0001$ \\
\hline & D-dimer & 0.278 & 0.035 \\
\hline & Fibrinogen & 0.517 & $<0.0001$ \\
\hline & LDH & 0.518 & $<0.0001$ \\
\hline & Procalcitonin & 0.366 & 0.005 \\
\hline \multirow[t]{10}{*}{ CT Severity score B } & variable & Spearman's $\rho$ & $p$ value \\
\hline & ANC & 0.298 & 0.020 \\
\hline & ALC & -0.460 & $<0.0001$ \\
\hline & N:L ratio & 0.470 & $<0.0001$ \\
\hline & $\mathrm{CD}^{+}$cells & -0.526 & 0.001 \\
\hline & $\mathrm{CD} 4^{+}$cells & -0.491 & 0.002 \\
\hline & $\mathrm{CD}^{+}$cells & -0.404 & 0.013 \\
\hline & CD16 ${ }^{+}$cells & -0.331 & 0.045 \\
\hline & ESR & 0.324 & 0.019 \\
\hline & CRP & 0.473 & $<0.0001$ \\
\hline
\end{tabular}

Page $12 / 20$ 


\begin{tabular}{|lllc|} 
& Ferritin & 0.548 & $<0.0001$ \\
\hline & Ferritin:ESR & 0.305 & 0.047 \\
\hline & Fibrinogen & 0.504 & $<0.0001$ \\
\hline LDH & Procalcitonin & 0.564 & $<0.0001$ \\
\hline & 0.349 & 0.008 \\
\hline $\begin{array}{l}\text { CT, computed tomography; ANC, absolute neutrophil count; ALC, absolute lymphocyte count; AMC, absolute monocyte } \\
\text { count; } N \text {, neutrophils:lymphocytes; Hb, hemoglobin; PLT, platelets; ESR, erythrocyte sedimentation rate; CRP, C reactive }\end{array}$ \\
\hline
\end{tabular}

Table 3. Differences across groups dividing patients according to age and gender. 


\begin{tabular}{|c|c|c|c|c|c|c|c|c|c|c|}
\hline \multirow{3}{*}{$N(\%)$} & \multicolumn{2}{|c|}{$<65$ years old } & \multicolumn{3}{|c|}{$\geq 65$ years old } & \multicolumn{2}{|c|}{ Females } & \multicolumn{3}{|l|}{ Males } \\
\hline & $30(49)$ & & $31(51)$ & & & $22(36)$ & & $39(64)$ & & \\
\hline & mean & SD & mean & SD & $\begin{array}{l}\text { p } \\
\text { value }^{1}\end{array}$ & mean & SD & mean & SD & $\begin{array}{l}p \\
\text { value }^{1}\end{array}$ \\
\hline Age (years) & & & & & & 69.05 & 17.48 & 64.31 & 13.26 & ns \\
\hline $\begin{array}{l}\text { Days of } \\
\text { symptoms } \\
\text { before CT }\end{array}$ & 5.67 & 3.00 & 5.71 & 3.36 & ns & 5.36 & 3.23 & 5.87 & 3.15 & ns \\
\hline $\begin{array}{l}\text { WBC } \\
\left.\text { (Nx10 } 10^{3} / \mathrm{LL}\right)\end{array}$ & 5.54 & 2.38 & 6.96 & 2.88 & ns & 5.80 & 2.75 & 6.52 & 2.70 & ns \\
\hline $\begin{array}{l}\text { ANC } \\
\left(\mathrm{N} \times 10^{3} / \mathrm{uL}\right)\end{array}$ & 3.90 & 2.32 & 5.29 & 2.72 & ns & 4.35 & 2.82 & 4.75 & 2.51 & ns \\
\hline $\begin{array}{l}\text { ALC } \\
\left(\mathrm{N} \times 10^{3} / \mathrm{uL}\right)\end{array}$ & 1.20 & 0.44 & 1.15 & 0.55 & ns & 1.11 & 0.41 & 1.22 & 0.54 & ns \\
\hline $\begin{array}{l}\text { AMC } \\
\left(\mathrm{N} \times 10^{3} / \mathrm{uL}\right)\end{array}$ & 0.38 & 0.18 & 0.49 & 0.29 & ns & 0.40 & 0.18 & 0.46 & 0.28 & ns \\
\hline N:L ratio & 3.88 & 3.37 & 6.26 & 5.34 & 0.027 & 4.99 & 4.57 & 5.11 & 4.66 & ns \\
\hline $\begin{array}{l}\text { CD3+ cells } \\
\text { (Nx103/uL) }\end{array}$ & 1024.89 & 427.01 & 773.78 & 407.17 & ns & 849.58 & 431.35 & 928.24 & 437.15 & ns \\
\hline $\begin{array}{l}\text { CD4+ cells } \\
\text { (Nx103/uL) }\end{array}$ & 582.74 & 231.31 & 464.50 & 209.61 & ns & 568.42 & 276.83 & 504.48 & 200.32 & ns \\
\hline $\begin{array}{l}\text { CD8+ cells } \\
\text { (Nx103/uL) }\end{array}$ & 423.05 & 237.93 & 300.06 & 228.90 & 0.048 & 275.67 & 175.59 & 405.24 & 256.11 & ns \\
\hline $\begin{array}{l}\text { CD19+ cells } \\
\text { (Nx103/uL) }\end{array}$ & 133.37 & 60.25 & 96.56 & 55.36 & ns & 115.33 & 59.85 & 115.52 & 61.42 & ns \\
\hline $\begin{array}{l}\text { CD16+ cells } \\
\text { (Nx103/uL) }\end{array}$ & 180.42 & 100.67 & 208.39 & 170.87 & ns & 176.17 & 90.74 & 202.60 & 156.76 & ns \\
\hline $\begin{array}{l}\text { CD4/CD8 } \\
\text { ratio }\end{array}$ & 2.00 & 1.96 & 2.01 & 1.01 & ns & 2.86 & 2.28 & 1.59 & 0.83 & 0.01 \\
\hline $\mathrm{Hb}(\mathrm{g} / \mathrm{L})$ & 13.63 & 1.34 & 12.72 & 1.95 & 0.015 & 12.33 & 1.23 & 13.67 & 1.79 & 0.003 \\
\hline PLTs & 207.80 & 80.51 & 237.13 & 79.42 & ns & 240.32 & 78.59 & 212.13 & 81.05 & ns \\
\hline $\mathrm{ESR}(\mathrm{mm} / \mathrm{h})$ & 62.93 & 32.82 & 69.61 & 26.42 & ns & 67.26 & 32.88 & 65.09 & 28.81 & ns \\
\hline CRP (mg/dl) & 4.30 & 4.58 & 6.02 & 4.78 & ns & 4.20 & 4.64 & 5.68 & 4.75 & ns \\
\hline Ferritin & 880.47 & 1052.24 & 743.93 & 797.27 & ns & 294.04 & 200.45 & 1096.89 & 1045.57 & $<0.0001$ \\
\hline $\begin{array}{l}\text { Ferritin:ESR } \\
\text { ratio }\end{array}$ & 25.25 & 45.31 & 15.11 & 22.30 & ns & 6.69 & 8.14 & 28.67 & 44.37 & 0.002 \\
\hline D-dimer & 0.93 & 0.58 & 2.36 & 3.62 & 0.005 & 1.46 & 1.08 & 1.84 & 3.40 & ns \\
\hline Fibrinogen & 572.10 & 178.55 & 540.21 & 118.66 & ns & 505.86 & 155.63 & 585.94 & 143.21 & ns \\
\hline LDH & 307.97 & 98.53 & 337.41 & 183.62 & ns & 287.74 & 132.26 & 339.84 & 150.15 & ns \\
\hline Procalcitonin & 0.17 & 0.30 & 0.26 & 0.40 & ns & 0.21 & 0.45 & 0.22 & 0.30 & ns \\
\hline $\mathrm{PaO2} / \mathrm{FiO} 2$ & 304.07 & 87.80 & 296.33 & 81.89 & ns & 330.29 & 89.30 & 282.92 & 77.09 & ns \\
\hline Severity score & 5.30 & 2.47 & 6.39 & 3.13 & ns & 5.18 & 2.34 & 6.23 & 3.06 & ns \\
\hline
\end{tabular}




$\begin{array}{llllllllllll}\text { Severity score } & 6.03 & 3.01 & 7.32 & 4.34 & \text { ns } & 5.73 & 2.98 & 7.23 & 4.09 & \text { ns }\end{array}$

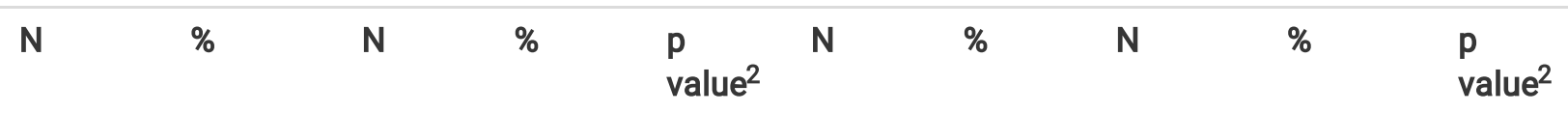

Gender

ns

$\begin{array}{lllll}\text { F } & 9 & 30 & 13 & 42 \\ \text { M } & 21 & 70 & 18 & 58\end{array}$

No. of lobes

ns

ns affected

\begin{tabular}{|c|c|c|c|c|c|c|c|c|c|c|}
\hline 1 & 1 & 3 & 1 & 3 & & 2 & 9 & 0 & 0 & \\
\hline 2 & 3 & 10 & 4 & 13 & & 2 & 9 & 5 & 13 & \\
\hline 3 & 5 & 17 & 2 & 6 & & 3 & 14 & 4 & 10 & \\
\hline 4 & 4 & 13 & 5 & 16 & & 4 & 18 & 5 & 13 & \\
\hline 5 & 17 & 57 & 19 & 61 & & 11 & 50 & 25 & 64 & \\
\hline \multirow{2}{*}{$\begin{array}{l}\text { Bilateral lung } \\
\text { disease }\end{array}$} & 28 & 93 & 30 & 97 & ns & 20 & 91 & 38 & 97 & ns \\
\hline & $\mathbf{N}$ & $\%$ & $\mathbf{N}$ & $\%$ & $\begin{array}{l}\text { p } \\
\text { value }^{2}\end{array}$ & $\mathbf{N}$ & $\%$ & $\mathbf{N}$ & $\%$ & $\begin{array}{l}\text { p } \\
\text { value }^{2}\end{array}$ \\
\hline $\begin{array}{l}\text { Type of } \\
\text { parenchymal } \\
\text { lesions }\end{array}$ & & & & & ns & & & & & ns \\
\hline
\end{tabular}

\begin{tabular}{|c|c|c|c|c|c|c|c|c|c|c|}
\hline $\begin{array}{l}\text { Neither } \\
\text { ground glass } \\
\text { opacities nor } \\
\text { consolidation }\end{array}$ & 0 & 0 & 0 & 0 & & 0 & 0 & 0 & 0 & \\
\hline $\begin{array}{l}\text { Ground glass } \\
\text { opacities only }\end{array}$ & 17 & 57 & 15 & 48 & & 9 & 41 & 23 & 59 & \\
\hline $\begin{array}{l}\text { Consolidation } \\
\text { only }\end{array}$ & 0 & 0 & 0 & 0 & & 0 & 0 & 0 & 0 & \\
\hline $\begin{array}{l}\text { Ground glass } \\
\text { opacities and } \\
\text { consolidation }\end{array}$ & 13 & 43 & 16 & 52 & & 13 & 59 & 16 & 41 & \\
\hline $\begin{array}{l}\text { Septal } \\
\text { thickening }\end{array}$ & 21 & 70 & 25 & 81 & ns & 15 & 68 & 31 & 79 & ns \\
\hline $\begin{array}{l}\text { Pleural } \\
\text { effusion }\end{array}$ & 4 & 13 & 7 & 23 & ns & 6 & 27 & 5 & 13 & ns \\
\hline $\begin{array}{l}\text { Mediastinal } \\
\text { lymph node } \\
\text { enlargement }\end{array}$ & 9 & 30 & 11 & 35 & ns & 9 & 41 & 11 & 28 & ns \\
\hline
\end{tabular}

${ }^{1} \mathrm{p}$ value calculated with Mann Whitney $\mathrm{U}$ test; ${ }^{2} \mathrm{p}$ value calculated with the $\chi^{2}$ test or the Fisher's exact test as needed.

SD. standard deviation; CT. computed tomography; WBC. white blood cells; ANC. absolute neutrophil count; ALC. absolute lymphocyte count; AMC. absolute monocyte count; N:L. neutrophils:lymphocytes; Hb. hemoglobin; PLT. platelets; ESR. erythrocyte sedimentation rate; CRP. C reactive protein; $L D H$. lactate dehydrogenase. 
Table 4. Differences across groups dividing patients according to ferritin levels.

Page 16/20 


\begin{tabular}{|c|c|c|c|c|c|}
\hline & Ferritin be & 5th percentile & Ferritin & 5th perce & \\
\hline$N(\%)$ & $13 / 51(25$ & & $38 / 51(7$ & & \\
\hline & mean & SD & mean & SD & p value ${ }^{1}$ \\
\hline Age & 63.62 & 18.79 & 65.95 & 14.51 & ns \\
\hline Days of symptoms before CT & 4.77 & 2.83 & 5.97 & 3.28 & ns \\
\hline WBC $\left(\mathrm{N} \times 10^{3} / \mathrm{uL}\right)$ & 5.22 & 2.45 & 6.30 & 2.65 & ns \\
\hline ANC $\left(\mathrm{N} \times 10^{3} / \mathrm{uL}\right)$ & 3.33 & 2.45 & 4.62 & 2.33 & 0.01 \\
\hline ALC (Nx10 $3 / \mathrm{uL})$ & 1.48 & 0.42 & 1.17 & 0.47 & 0.02 \\
\hline AMC (Nx103/uL) & 0.42 & 0.18 & 0.45 & 0.27 & ns \\
\hline N:L ratio & 2.51 & 2.31 & 4.80 & 4.07 & 0.002 \\
\hline CD3+ cells (Nx103/uL) & 1088.60 & 408.16 & 848.48 & 411.35 & ns \\
\hline CD4+ cells (Nx103/uL) & 651.10 & 273.75 & 478.96 & 185.92 & ns \\
\hline CD8+ cells (Nx103/uL) & 426.50 & 196.91 & 352.48 & 246.63 & ns \\
\hline CD19+ cells (Nx103/uL) & 133.30 & 54.86 & 103.65 & 56.64 & ns \\
\hline CD16+ cells (Nx103/uL) & 218.40 & 105.77 & 190.91 & 157.78 & ns \\
\hline CD4/CD8 ratio & 1.73 & 0.71 & 1.97 & 1.78 & ns \\
\hline $\mathrm{Hb}(\mathrm{g} / \mathrm{L})$ & 12.28 & 1.22 & 13.38 & 1.87 & 0.04 \\
\hline PLTs & 237.85 & 66.10 & 218.76 & 83.37 & ns \\
\hline ESR (mm 1h) & 52.91 & 28.98 & 69.06 & 30.06 & ns \\
\hline CRP (mg/dl) & 3.00 & 3.83 & 5.59 & 4.37 & 0.01 \\
\hline D-dimer & 1.07 & 1.01 & 2.05 & 3.40 & ns \\
\hline Fibrinogen & 457.08 & 107.60 & 580.27 & 156.66 & 0.01 \\
\hline LDH & 238.67 & 77.55 & 353.37 & 145.55 & 0.01 \\
\hline procalcitonin & 0.10 & 0.22 & 0.23 & 0.29 & 0.0003 \\
\hline $\mathrm{PaO2/Fi02}$ & 349.69 & 82.63 & 284.63 & 78.91 & 0.02 \\
\hline Severity scoreA & 3.23 & 1.88 & 6.45 & 2.77 & 0.0004 \\
\hline Severity score B & 3.38 & 2.06 & 7.39 & 3.68 & 0.0004 \\
\hline & $\mathbf{N}$ & $\%$ & $\mathbf{N}$ & $\%$ & p value ${ }^{2}$ \\
\hline Gender & & & & & 0.003 \\
\hline $\mathbf{F}$ & 9 & 69 & 9 & 24 & \\
\hline M & 4 & 31 & 29 & 76 & \\
\hline No. of lobes affected & & & & & $<0.0001$ \\
\hline 1 & 2 & 15 & 0 & 0 & \\
\hline
\end{tabular}




\begin{tabular}{|c|c|c|c|c|c|}
\hline 2 & 5 & 38 & 2 & \multicolumn{2}{|l|}{5} \\
\hline 3 & 1 & 8 & 5 & \multicolumn{2}{|l|}{13} \\
\hline 4 & 3 & 23 & 4 & \multicolumn{2}{|l|}{11} \\
\hline 5 & 2 & 15 & 27 & \multicolumn{2}{|l|}{71} \\
\hline Bilateral lung disease & 10 & 77 & 38 & 100 & 0.002 \\
\hline \multicolumn{5}{|l|}{ Type of parenchymal lesions } & \multirow[t]{2}{*}{ ns } \\
\hline Neither ground glass opacities nor consolidation & 0 & 0 & 0 & 0 & \\
\hline Ground glass opacities only & 8 & 62 & 19 & \multicolumn{2}{|l|}{50} \\
\hline Consolidation only & 0 & 0 & 0 & \multicolumn{2}{|l|}{0} \\
\hline Ground glass opacities and consolidation & 5 & 39 & 19 & \multicolumn{2}{|l|}{50} \\
\hline Septal thickening & 5 & 38 & 32 & 84 & 0.001 \\
\hline Pleural effusion & 5 & 38 & 4 & 11 & 0.02 \\
\hline Mediastinal lymph node enlargement & 1 & 8 & 14 & 37 & 0.05 \\
\hline \multicolumn{6}{|c|}{$\begin{array}{l}\text { SD. standard deviation; CT. computed tomography; WBC. white blood cells; ANC. absolute neutrophil count; ALC. absolute } \\
\text { lymphocyte count; AMC. absolute monocyte count; N:L. neutrophils:lymphocytes; Hb. hemoglobin; PLT. platelets; ESR. } \\
\text { erythrocyte sedimentation rate; CRP. C reactive protein; } L D H \text {. lactate dehydrogenase; } M \text {. male; F. Female. }\end{array}$} \\
\hline
\end{tabular}

Table 5. Characteristics of patients according to the outcome. 


\begin{tabular}{|c|c|c|c|c|c|c|c|c|c|c|}
\hline & \multicolumn{6}{|c|}{ Discharged } & \multicolumn{4}{|c|}{ Deceased $(\mathrm{N}=5)$} \\
\hline & \multicolumn{2}{|c|}{ All $(N=56)$} & \multicolumn{2}{|c|}{$\begin{array}{l}\text { with ICU } \\
\text { admission } \\
(\mathrm{N}=5)\end{array}$} & \multicolumn{2}{|c|}{$\begin{array}{l}\text { without ICU } \\
\text { admission } \\
(\mathrm{N}=51)\end{array}$} & \multirow[b]{2}{*}{ Mean } & \multirow[b]{2}{*}{ SD } & \multirow[b]{2}{*}{$\begin{array}{l}\text { p value } \\
\text { discharged } \\
\text { vs } \\
\text { deceased }^{1}\end{array}$} & \multirow[b]{2}{*}{$\begin{array}{l}\text { p value } \\
\text { discharged } \\
\text { with vs } \\
\text { without ICU } \\
\text { admission } 1\end{array}$} \\
\hline & Mean & SD & Mean & SD & Mean & SD & & & & \\
\hline Age & 64.9 & 14.9 & 69.6 & 8.6 & 64.5 & 15.4 & 78.4 & 9.3 & 0.039 & ns \\
\hline $\begin{array}{l}\text { Days of } \\
\text { symptoms } \\
\text { before CT }\end{array}$ & 5.8 & 3.2 & 4.4 & 3.0 & 5.9 & 3.2 & 4.6 & 2.3 & ns & ns \\
\hline WBC (Nx10³/uL) & 6.0 & 2.5 & 8.3 & 4.0 & 5.7 & 2.2 & 9.7 & 3.4 & 0.023 & ns \\
\hline ANC $\left(\mathrm{N} \times 10^{3} / \mathrm{uL}\right)$ & 4.3 & 2.3 & 6.1 & 3.4 & 4.1 & 2.1 & 8.5 & 3.3 & 0.005 & ns \\
\hline ALC $\left(\mathrm{N} \times 10^{3} / \mathrm{uL}\right)$ & 1.2 & 0.5 & 1.3 & 0.7 & 1.2 & 0.5 & 0.8 & 0.2 & ns & ns \\
\hline AMC (Nx103/uL) & 0.4 & 0.2 & 0.8 & 0.5 & 0.4 & 0.2 & 0.5 & 0.3 & $\mathrm{~ns}$ & ns \\
\hline N:L ratio & 4.5 & 4.0 & 8.1 & 8.8 & 4.2 & 3.3 & 11.6 & 6.4 & 0.004 & ns \\
\hline $\mathrm{Hb}(\mathrm{g} / \mathrm{L})$ & 13.2 & 1.6 & 13.5 & 2.2 & 13.2 & 1.5 & 12.6 & 3.2 & ns & ns \\
\hline PLTs & 220.7 & 79.6 & 214.0 & 69.0 & 221.2 & 80.9 & 242.2 & 99.9 & ns & ns \\
\hline $\operatorname{ESR}(\mathrm{mm} 1 \mathrm{~h})$ & 65.3 & 30.4 & 48.3 & 18.5 & 66.5 & 30.8 & 74.7 & 26.9 & ns & ns \\
\hline CRP (mg/dl) & 4.8 & 4.5 & 7.0 & 4.2 & 4.6 & 4.5 & 9.2 & 6.1 & ns & ns \\
\hline ferritin & 766.1 & 841.6 & 1057.0 & 582.6 & 732.2 & 865.5 & 1572.9 & 2005.5 & ns & ns \\
\hline ferritin:ESR ratio & 19.7 & 36.8 & 24.7 & 25.4 & 19.3 & 37.7 & 47.4 & 57.6 & ns & ns \\
\hline D-dimer & 1.7 & 2.9 & 3.6 & 4.6 & 1.5 & 2.6 & 1.8 & 1.3 & ns & 0.037 \\
\hline Fibrinogen & 554.7 & 156.6 & 577.6 & 119.7 & 552.4 & 160.8 & 579.0 & 56.3 & ns & ns \\
\hline LDH & 300.6 & 98.8 & 389.0 & 98.3 & 291.4 & 95.2 & 703.0 & 310.5 & 0.009 & 0.044 \\
\hline procalcitonin & 0.2 & 0.3 & 0.3 & 0.2 & 0.2 & 0.3 & 0.9 & 0.8 & 0.015 & ns \\
\hline $\mathrm{PaO2} / \mathrm{FiO} 2$ & 307.6 & 82.8 & 199.2 & 72.7 & 318.9 & 75.8 & 220.0 & 55.0 & 0.008 & 0.002 \\
\hline $\begin{array}{l}\text { CT Severity } \\
\text { scoreA }\end{array}$ & 5.7 & 2.6 & 8.6 & 3.7 & 5.4 & 2.3 & 8.0 & 4.6 & ns & 0.022 \\
\hline \multirow[t]{2}{*}{$\begin{array}{l}\text { CT Severity score } \\
\text { B }\end{array}$} & 6.4 & 3.3 & 9.8 & 4.5 & 6.0 & 3.0 & 10.2 & 6.9 & ns & 0.033 \\
\hline & $\mathbf{N}$ & $\%$ & $\mathbf{N}$ & $\%$ & $\mathbf{N}$ & $\%$ & $\mathbf{N}$ & $\%$ & $\begin{array}{l}\text { p value } \\
\text { discharged } \\
\text { vs } \\
\text { deceased }^{2}\end{array}$ & $\begin{array}{l}\text { p value } \\
\text { discharged } \\
\text { with vs } \\
\text { without ICU } \\
\text { admission² }\end{array}$ \\
\hline Gender & & & & & & & & & ns & ns \\
\hline $\mathrm{F}$ & 20 & 36 & 0 & 0 & 20 & 39 & 2 & 40 & & \\
\hline
\end{tabular}




\begin{tabular}{|c|c|c|c|c|c|c|c|c|c|c|}
\hline M & 36 & 64 & 5 & 100 & 31 & 61 & 3 & 60 & & \\
\hline $\begin{array}{l}\text { Age over } 65 \\
\text { years }\end{array}$ & 26 & 46 & 4 & 80 & 22 & 43 & 5 & 100 & ns & ns \\
\hline $\begin{array}{l}\text { No. of lobes } \\
\text { affected }\end{array}$ & & & & & & & & & ns & ns \\
\hline 1 & 2 & 4 & 0 & 0 & 2 & 4 & 0 & 0 & & \\
\hline 2 & 6 & 11 & 1 & 20 & 5 & 10 & 1 & 20 & & \\
\hline $\begin{array}{l}\text { No. of lobes } \\
\text { affected }\end{array}$ & $\mathbf{N}$ & $\%$ & $\mathbf{N}$ & $\%$ & $\mathbf{N}$ & $\%$ & $\mathbf{N}$ & $\%$ & $\begin{array}{l}\text { p value } \\
\text { discharged } \\
\text { vs } \\
\text { deceased }^{2}\end{array}$ & $\begin{array}{l}\text { p value } \\
\text { discharged } \\
\text { with vs } \\
\text { without ICU } \\
\text { admission² }\end{array}$ \\
\hline 3 & 7 & 13 & 0 & 0 & 7 & 14 & 0 & 0 & & \\
\hline 4 & 7 & 13 & 1 & 20 & 6 & 12 & 2 & 40 & & \\
\hline 5 & 34 & 61 & 3 & 60 & 31 & 61 & 2 & 40 & & \\
\hline $\begin{array}{l}\text { Bilateral lung } \\
\text { disease }\end{array}$ & 53 & 95 & 5 & 100 & 48 & 94 & 5 & 100 & ns & ns \\
\hline \multicolumn{11}{|l|}{$\begin{array}{l}\text { Type of } \\
\text { parenchymal } \\
\text { lesions }\end{array}$} \\
\hline $\begin{array}{l}\text { Neither ground } \\
\text { glass opacities } \\
\text { nor } \\
\text { consolidation }\end{array}$ & 0 & 0 & 0 & 0 & 0 & 0 & 0 & 0 & & \\
\hline $\begin{array}{l}\text { Ground glass } \\
\text { opacities only }\end{array}$ & 31 & 55 & 2 & 40 & 29 & 57 & 1 & 20 & & \\
\hline $\begin{array}{l}\text { Consolidation } \\
\text { only }\end{array}$ & 0 & 0 & 0 & 0 & 0 & 0 & 0 & 0 & & \\
\hline $\begin{array}{l}\text { Ground glass } \\
\text { opacities and } \\
\text { consolidation }\end{array}$ & 25 & 45 & 3 & 60 & 22 & 43 & 4 & 80 & & \\
\hline Septal thickening & 41 & 73 & 4 & 80 & 37 & 73 & 5 & 100 & ns & ns \\
\hline Pleural effusion & 9 & 16 & 1 & 20 & 8 & 16 & 2 & 40 & ns & ns \\
\hline $\begin{array}{l}\text { Mediastinal } \\
\text { lymph node } \\
\text { enlargement }\end{array}$ & 18 & 32 & 1 & 20 & 17 & 33 & 2 & 40 & ns & ns \\
\hline $\begin{array}{l}{ }^{1} \mathrm{p} \text { value calculate } \\
\text { CT, computer tom } \\
\text { count; } A L C, \text { absol } \\
\text { platelets; } E S R \text {, eryt }\end{array}$ & $\begin{array}{l}\text { wiith } \\
\text { rrapl }\end{array}$ & $\begin{array}{l}\mathrm{n} W \\
U, \text { in }\end{array}$ & ey L & $\begin{array}{l}\text { o valu } \\
\text { it; SD, } \\
\text { solute } \\
\text { PP, C re }\end{array}$ & $\begin{array}{l}\text { Alcula } \\
\text { ndarc } \\
\text { onoc }\end{array}$ & $\begin{array}{l}\text { with } \\
\text { jiatic }\end{array}$ & $x^{2} t$ & $\begin{array}{l}\text { he Fisl } \\
\text { blood } \\
\text { Is:lym } \\
\text { droge }\end{array}$ & $\begin{array}{l}\text { exact test as } \\
\text {; ANC, absolu } \\
c y t e s ; H b \text {, hen } \\
e ; M, \text { male; } F \text {, }\end{array}$ & $\begin{array}{l}\text { eeded. } \\
\text { e neutrophil } \\
\text { oglobin; PLT, } \\
\text { male. }\end{array}$ \\
\hline
\end{tabular}

